UDC: $372.4: 371.2+82$

DOI: https://doi.org/10.24195/2414-4665-2017-5-20

Gabriela Šarníková,

PhD, associate professor,

Department of Christian Education,

Sts. Cyril and Methodius Faculty of Theology

Palacký University, 22, Univerzitní Str., Olomouc, Czech Republic

\title{
DEVELOPMENT OF CRITICAL THINKING OF PRIMARY SCHOOL PUPILS THROUGH LITERARY TEXTS
}

This study attempts to characterize the development of critical thinking according to Philosophy for Children ('P4C') approach and related literature during the educational process through the method of discussion - based on literary texts. The qualitative research carried out as a part of extra-curricular activities of primary-school pupils in Slovak school was aimed at conducting philosophical discussions with children. The first purpose of the research was to find out the pupils' opinions about the texts used during the discussions. The second purpose was to find out whether the Slovak primary-school textbooks approved by the Ministry of Education contain texts suitable for philosophical discussions with children. In order to achieve the set objectives, two methodical approaches from the area of qualitative research were used. In the first case the interpretative phenomenological analysis ('IPA') with focus on the analysis of data from discussions with children was applied. In the second case, the textbooks were subjected to a textual content analysis. According to the research outcomes, the respondents positively reacted to the reading of various texts as well as the related discussions. It is worth noting that the criminal stories got the most positive reactions. This fact could build a basis for further consideration and examination. When it comes to the analysis of textbooks, apart from one exception there have not been discovered any philosophical texts for children in the primary-school textbooks. Though there have been found enough texts to develop philosophical thinking of pupils, for philosophical exercises, as well as for philosophical discussions, especially in the reading books.

Keywords: thinking skills, Philosophy for Children, extra-curricular activities, children's literature, textbook.

\section{Introduction}

"Thinking skills are influential in almost every discipline and occupation" (Ghanizadeh, 2017, 102), as well as in everyday life with other people. The development of critical and creative thinking of pupils as a part of the development of cognitive competencies and thinking skills has been explicitly incorporated in Slovak curricular materials only in 2008.

One of the ways of the development of critical thinking - that is a part of philosophical thinking - is a discussion of community of inquiry. It is embodied in an educational approach "Philosophy for Children" ('P4C'). The proponents of the Philosophy for Children believe that critical, self-correcting and independent thinking has to be developed since childhood, however not as thinking in solitude, but as a part of community. Independent thinking is related to sharing opinions, listening, deliberation, and acting. The point is not to think or say something different than others or being entitled to think whatever one wants. The point is the willingness to start the process of critical examination of reasoning (Splitter \& Sharp, 1995). The endeavour is to seek and find reasons and thoughts together with others - these others necessary for the cultivation of thinking and betterment and deepening of one's own thoughts.

Theoretical background

Discussion method among/with children in the P4C approach
Matthew Lipman started to develop the idea of children's independent and self-correcting thinking in the 1960s. His claim was that it is the means of personal development and a basis for the good future of the society. He drew on the psychological and philosophical assumptions on the possibility and necessity of cognitive development of children.

In his view, the best method to develop thinking is discussion. In terms of methodology he drew here on Socrates and Plato and their way of 'teaching'. The P4C approach uses the discussion as a pillar supporting the development of multidimensional thinking, i.e. the development of critical and creative thinking. The discussion has also social and ethical dimension.

Discussion topics are chosen mainly from children's literature, either from novels or stories, aimed at $\mathrm{P} 4 \mathrm{C}$ related objectives.

The discussion starts by choosing an issue on which the participants of the discussion voice opinions and the discussion finishes with reflection. The discussion in the community of inquiry should be spontaneous, but guided and prepared.

The educator has to prepare the theoretical aspect of the discussion, to guide it and to actively take part as an equal member, partner, as a part of the community of inquiry, who during the discussion often does not know more than the pupils (Lipman, 2008), even if they think that he/she does. The educator is not a mentor, but a facilitator, a coordinator. Generally, he/she helps the 
community of children to shape the discussion in order to apply the principles of logic and informal thinking. $\mathrm{He} / \mathrm{she}$ should handle the shaping (formation) of the changing community of inquiry, steer the children towards thinking for themselves about philosophical questions, observe, how they get involved in the discussion on the issues tackled by the characters in the stories. He/she helps the children to become more aware of the process of reasoning.

The community of inquiry respects the freedom of speech of every member, thereby developing democratic outlooks. Emphasis is on the development of coherent and clear thinking, unafraid of a dialogue. The participants should express their doubts about the opinions of others with dignity, respect and properly so as to form their own judgements.

Literature for philosophical discussion and the other kinds of literature for children

P4C novels and stories focus on problems coming up in the history of philosophy and the children are learning to examine them in terms of philosophy. The point is not to learn theories or adopt the opinions of philosophers, but to gain skills necessary to express their own observations using vocabulary close to them. The point is also not to pass down philosophical tradition but to transform the history of philosophy by considering essential philosophical problems as means serving to develop and deepen the self-correcting thinking.

The main protagonists are the children's peers. The stories should prompt a philosophical discussion, get the reader to think about and examine parts of the story and analyse concepts coming up in the story or in life. This type of work always contains philosophical questions. They are not answered explicitly; the answer should be discovered by the reader in the discussion.

A story read in a community of children should bridge the distance between them and the philosophical culture they belong to and which they, thanks to the story, get to know and understand better. The stories acquaint the children with thoughts of many philosophers. Neither names of the philosophers, nor historical data are necessary for a child to absorb the philosophical culture, just the ideas of the thinkers. Such a text should convey the legacy of philosophical thinking so that the children are able to understand and build on it. A philosophical story for children should allow for 'reflection about culture conveyed through literary characters and develop the ability to take a critical stand towards reality' (Sasseville and Gagnon, 2011, p. 20). A philosophical story is the starting point and the discussion is the 'link', as well as the pillar of the approach.

The first stories for philosophical discussion with children were written by M. Lipman, who writes on his beginnings (1992, p. 22):

"The idea of a children's story was suggested to me. But what kind of a children's story? Surely not the kind in which all-knowing adults benevolently explain to ignorant little folk the differences between thinking well and think- ing badly. Nothing so condescending. This would have to be something young people would discover for themselves, with little help from grown-ups. The children in the story would somehow have to constitute a small community of inquiry, in which everyone shared, at least to some extent, in cooperatively searching for and discovering more effective ways of thinking. It was my thought that the little band of children in the story could serve as a model with which the live students in the classroom might identify. Such a portrait of children living together intelligently and with mutual respect, might give children hope that such an ideal was feasible (as Plato's dialogues had done for adults)"

The protagonists are not typical characters and each of them is original. The differences between them are in their way of thinking - some think intuitively, some more analytically, others are sceptical or tend to experiments. No way of thinking is presented as being better or worse. The stories contain a lot of keywords in order to prompt the children's thoughts and questions. These are no easy concepts to explain, however they create interest and instigate a discussion. Even though from a certain point of view the text appears to be philosophical; there are no terms and definitions. It is written to be accessible to children. The aim is not to communicate knowledge (as a textbook would), but a process allowing the children to learn to think. The protagonists in the stories should be peers of the children. The questions in their dialogues arise from their interests and are accessible to the skills of the readers.

Some of Lipman's texts are written in the first person, with the main protagonist communicating with the reader. The story engages the reader in the life of the characters and at the same time lets him/her think in peace. When identifying with a character the reader undergoes the same shift in thinking. Many characters appear in several novels. The thinking has to be coupled with a strong emotional engagement to ensure the standards and the criteria of the protagonist's thoughts and statements.

Some researches show that through empathy readers may identify themselves with protagonists (see Peer, Chesnokova, Springer, 2017; Trelease, 2013).

Lipman's first work was the novel Harry Stottlemeier's Discovery (1974) (The name Stottlemaier was created as wordplay on Aristotle's name) with the manual Philosophical Inquiry. It is meant for 11 to 12 -year-old readers. The focus is on formal justification, controversies, syllogistic reasoning, relational logic, informal fallacy, contradictions and hypothetical thinking. The author hoped that his missteps and embarrassments will endear Harry to the readers more easily, than if he was some virtuous and infallible hero or some of 'academic' or 'overachiever'.

The novel Pixie (Lipman, 1981) for 9 to 10-year-olds is accompanied by the manual Looking for Meaning and its purpose is to develop philosophical skills such as inclusion (comprehension) and exclusion (exemption) and 
discovery of assumptions. Many readers can identify themselves with Pixie (it is the name of the main protagonist, which she gave to herself), ask questions and look for answers together with her, at the same time improving their thinking.

Between 1973 and 1988 Lipman wrote more philosophical novels for children. Kio and Gus (1982) for the 8 to 9-year-olds and the manual Wondering at the World have a goal similar to Pixie. However, while Pixie focuses on the skills of finding analogies and causes and on the philosophy of language, Kio and Gus puts emphasis on employing the variability of logical thinking when exploring the nature. Elfie (1987) with the manual Getting our Thoughts Together is for 6-7-year-olds and is focused on the formation of differences, relationships, connections and comparisons on a wide scale of philosophical questions. Lisa (1976) is a novel for 13-14-year-olds, its manual is titled Ethical Inquiry and it deals with ethical questions. The characters from the novel Suki (1978) for 1516-year-old readers are explorers in the field of aesthetics. The manual is titled Writing: How and Why. For 17-18years-olds Lipman wrote stories called Mark (1980) and the manual Social Inquiry. Those deal with the topic of social and political exploration. In 1996 Lipman wrote a novel Nous with the manual Deciding What to Do. One of the main protagonists is once again Pixie.

Before long Lipman was joined by other proponents of the approach and in a short time more philosophical novels for children started cropping up, not only in the US but also in other countries where $\mathrm{P} 4 \mathrm{C}$ has spread.

So far there are no Slovak translations of the books, though some were published in Czech. However, most of them were missing the translation of the manuals.

Works of fiction are not supposed to provide the reader with tools necessary for actual philosophical thinking. They do not address the issue of formulating concepts, thoughts and analyses and they also do not address open (unsolved) questions and dialogue, formulating of speculative and creative hypotheses on the nature of things, shaping of the structure of arguments and fallacies or the creation of stories through exploration - reflection and self-correction. Works of fiction consider the key issues to be the analysis of the plot and the literary characters, their development, the literary means of expression, the hidden meaning etc.; however, what the philosophy is looking for is a path to the thinking, strategies and thoughts beneath the surface of the story. These processes often become the focal point of a philosophical discussion.

In comparison to the teaching materials aimed at the development of critical thinking and understanding the word, literature for philosophical discussion does not provide complete answers; instead the children are prompted to ask questions, which should lead them to the answers. A philosophical story represents an often sad and painful reality, similar to the one with which the children are dealing. The discussion should teach the children how to cope with problems, have opinions, assess things etc. Along with the philosophical thinking of children, creativity and emotionality undergo development and deepening as well (Lipman at al., 1980). Textbooks are written in order to communicate information and facts, mostly without prompting independence and deepening of the thinking process. Even though most textbooks contain questions, their function is primarily diagnostic - the pupil can test out his/her ability to reiterate the information, his/her understanding of the text. According to Lipman (1988) for children to master scientific knowledge (in particular natural science), they have to adopt a scientific way of thinking. That is however not an end that the textbook materials would aspire to. A philosophical story should prompt the children to explore philosophical concepts and philosophical processes in direct relation to their experience.

Stories and novels for philosophical discussions with children should entice them to take part in a constant philosophical discussion about important as well as common everyday controversies and concepts based on human experience. In these terms their purpose is didactical (Martin, 1993).

The methodical guides (manuals) to the novels contain mainly ideas and roadmaps for future discussions and exercises to develop philosophical skills and deepen the critical, creative and engaged thinking (Lipman, 2003). Traditional literature for children and youth does not have such didactic purpose, and the stories are not accompanied by manuals on how to involve children in philosophy.

A group discussion of a story - as opposed to traditional textbooks - enables children to control the text, steer it, as they have the helm in their hands. It is their story, they use it to discuss, explore the philosophy, search. Textbook materials are never subject to such an approach, and not every work of fiction allows for deepening the critical and philosophical thinking.

\section{The empirical part}

\section{The rationale}

Although from its beginnings the $\mathrm{P} 4 \mathrm{C}$ approach underwent development as well as modifications; the main characteristics are remaining unchanged. In the countries where $\mathrm{P} 4 \mathrm{C}$ has taken roots, its supporters today also use other means to start a philosophical discussion. Some proponents of $\mathrm{P} 4 \mathrm{C}$ create stories and scenarios based on typical school situations, experiences from home or on media reports.

There are opinions that a philosophical discussion in a community of inquiry could also be based on works of fiction containing philosophical ideas. According to L. Macků (2010) after cracking the metaphors (which are missing in the philosophical story) the children could look for philosophical topics and reflections and then continue in line with the P4C methods.

Supporters and propagators of $\mathrm{P} 4 \mathrm{C}$ introduce alternate ways to initiate the discussion. They draw not only from literary texts but also other media (drawing, painting, and illustration), advertising posters, short movies, 
music, as well as the creative approach to the material, etc.

In Slovakia P4C has not taken roots yet, even though the school system has been undergoing permanent changes since 1989. In the Czech Republic, the country closest to the changes in the school system in Slovakia, the Centre of Philosophy for Children was established. In Slovakia, new curricular material - the National educational programme - was created in 2008, outlining educational matters in line with international classification. It contains previously undefined concepts (competencies, content and performance standards, field of education, 'ISCED“, etc.), thereby coming closer to the international terminology as well as the educational goals and content. As of September 2015, the improved national educational programmes are in effect in response to the reaction of experts on the necessity of adapting the documents from 2008.

New textbooks are being prepared in line with the content of the curricular materials. For use in Slovakia, textbooks have to pass the selection procedure and get approval from the Ministry of Education.

Given that $\mathrm{P} 4 \mathrm{C}$ is not being developed in Slovakia and there are no philosophical novels for children, we were interested in texts that could be used to develop cognitive competencies in line with $\mathrm{P} 4 \mathrm{C}$, texts that would comply with the requirements of the educational programme for primary schools in any ordinary school. The primary level of education in Slovakia consists of years 1 . to 4.; the first year is attended by children the age of six.

\section{Research objectives}

In our research of the matter in hand we have proposed two tasks with two related objectives.

The first task revolved around determining the children's opinions on the used texts and the suitability of texts for philosophical discussion - all based on discussion and the practical pursuit of philosophical discussions.

The second task put the focus on the analysis of primary-school textbooks in Slovakia in terms of the texts for pupils.

Our attention was focused on two phenomena: the opinions of the participants of focus groups and the textbooks for primary-school pupils. follows:

The objectives of our examinations were defined as

1. Determining the pupil's opinion on a text used during the discussion.

2. Determining whether the Slovak primary-school textbooks approved by the Ministry of Education contain texts suitable for philosophical discussions with children.

\section{Research methods}

In order to achieve the set objectives, we have used two methodical approaches from the area of qualitative research. In the first case we used interpretative phenomenological analysis ('IPA') (Creswell, 2007; Smith, Flowers and Larkin, 2013) with focus on the analysis of data from discussions with children and in the second case we subjected the textbooks to a textual content analysis (Gavora, 2007; Hendl, 2008; Silverman, 2000).
Discussions with pupils and interpretative phenomenological analysis

The qualitative research, the results of which we present, monitored the critical thinking of pupils during afterschool activities in the school years 2012/2013 and 2013/2014 in a group based on P4C. This study focuses on the opinions of the participants on the texts used.

\section{Focus groups}

During the after-school activities 28 discussions with two focus groups of pupils of a parochial primary school took place in a district capital (population of up to 30 000) in central Slovakia. First, we informed pupils of $4^{\text {th }}$ and $5^{\text {th }}$ grades and their parents about the opportunity to participate in this after-school activity. Those enrolled could become participants of our groups. We labelled them A and $\mathrm{B}-\mathrm{A}$ is the group from the first year, $\mathrm{B}-$ from the second. The A group included eight pupils - four from one class (one girl, three boys) and four from another class (two girls, two boys). B group consisted of nine pupils, four boys from the fourth year and five pupils from the fifth year (two boys from one class and three pupils from another - two girls and one boy). The results of our study do not exclude the pupils from the fifth year, as the age differences between the participants were irrelevant. All sessions and discussions were recorded on videotapes. The legal representatives signed permission for the recording and publishing of results, on the condition that the recordings will serve only for research purposes. Eleven sessions with the first focus group averaged 60 minutes and took place only in the second half of the year. 17 further sessions with the B group averaged approximately 110 minutes and took place throughout the whole year. The groups' main activity consisted of reading a text and its discussion. Some sessions omitted reading and the discussion was based on other activities. Drawing, writing and other text-related activities to develop critical and creative thinking also took place. Given the partial objectives of our research we used only the recordings pertaining to our study.

Our research applies the IPA to transcribed discussions. Each line of transcription was numbered and the transcribed text analysed. The first step included taking notes in a column to the right side of the transcript with the aim to abstract and select significant and attentiongrabbing questions. Next we have looked for connections between individual questions and grouped the issues accordingly. For the purposes of this study we have focused on the participants' opinions on the literature used in the reading group. This question was part of the reflection at the end of each session.

\section{Used literature}

The reading group used literature written directly for the purpose of philosophical discussion, as well as other texts.

Since no P4C literature was published in Slovak, we have decided to use also Czech translations, since as the language is understood by Slovak children and they had no objections against reading Czech texts. The same 
was applied to B group. We have read the books Blanka and Jirka (French orig. Grégoire et Béatrice) as well as Lukáš and Lenka (French orig Fabienne et Loïc) by Pierre Laurendeau (2011a, 2011b). We translated stories from the novel Elfie by Matthew Lipman from Czech to Slovak; the participants had the text at their disposal.

We also read Hitler's Daughter by Jackie French (2009). The book is not written explicitly for the purpose of $\mathrm{P} 4 \mathrm{C}$, but the contents and the writing style correspond to a philosophical novel for children. The book came out in a Czech translation, but for the purposes of the reading group we have translated the text into Slovak.

Aside from this literature we have used Arnold Lobel's stories about the frogs Frog and Tod (2008), even though these are not $\mathrm{P} 4 \mathrm{C}$ texts.

Another source was the adventures of Priesemut and Nulli - the hare and the frog - by Matthias Sodtke (2011) and a story about courage by Lorenz Pauli (2009). These stories were written in German and were published neither in Czech nor in Slovak, they are however recommended by Eva Zoller Mort, so we arranged to work with a text translated solely for the purpose of the reading group.

We also used another text, in a more or less experimental approach. It was a set of crime mysteries with an open ending by Hy Conrad (2006), in Czech translation called Kdo je pachatel? (Engl. orig. Whodunit Crime Mysteries). These books also lack a Slovak translation, however having read the Czech texts of philosophical novels, we have decided to use the Czech translation, with the participants having no trouble with that.

The A group has read Frog and Tod and Hitler's Daughter. The other books were read in the second year.

The texts were always read aloud. With Slovak texts, the reading was done by the participants, the Czech text was read by the educator and the participants listened to him. The reading was followed by explanations of unknown words and afterwards we followed the P4C methods.

First the questions were asked, explained and clarified, and then the issue was chosen which the participants wanted to discuss. During the final reflection they had to assess, how they liked the session, the positives and negatives, what should be changed, etc. One question addressed the type of the text used.

The stories about the frogs Frog and Tod were met with the following commentary of the participant: That is for kindergartners, but the discussion is good (A4009). When we switched from reading Frog and Tod to another book, the reaction was: Why not Frog and Tod anymore? It was good (A6189).

The announcement that we are going to read a book called Hitler's Daughter (the title is a fiction) prompted the reactions: He had a daughter? (A6227). He did not like children, he tortured and killed them (A6231). He was a fascist (A6400). Hitler did not have a daughter (A6402). A commentary on the story itself: Now that is wicked (A6444). After finishing the reading on one day, the participants reacted: We wanted more about the Hitler's daughter (A6260). During another session we discovered that some children were really taken with the topic of Hitler during the week, and they wanted to discuss the issue more: Hitler liked children - I found that out in a documentary (A6974). He did like children, didn't he? (A6977). Yes, I found out, that he did (A6987). But he could not stand them (A6980). But then he did (A6981). Hitler had a daughter, that's what I said (A7212), I have seen a documentary about that (A7215). In the next session there was the question: Will we continue that reading? (A7171). A positive answer met with the reaction: Yes (A7174). Read us more (A8215). Today's session was good, because we have read (A8400). However, the participants were more inclined to read than to discuss the novel's topics (A8940).

The second year we read different books and recorded the reactions of the participants.

The book on courage warranted the following statements: I liked the session because of the story that we read (B2387). I liked that story (B2390). I liked the story and the whole session (B2392). I also liked the story (B2401). I liked today's story (B2418). I liked the session, because we listened to a story (B2425).

The story about Nulli and Priesemut got the following reactions: I liked the session very much (B3487). I liked this one too (B3491). I will like it, when we read these stories that are to be continued (B3507). After a while one of the participants said in regard to the story: I have written something similar for my mother's namesday (B16036).

We have also read books written specifically for $\mathrm{P} 4 \mathrm{C}$ Blanka a Jirka as well as Lukáš a Lenka. After the announcement that we will read one chapter in each session, one participant reacted: Yippeeee! (B3798). During the reflection on the text: I liked that we have read this story (B4636). I liked the story (B4639). I liked this fairy-tale (B6439). I liked it - this story (B6441). I liked the whole session and especially the story and drawing (B6467). I liked the story (B30647). It was nice, because we have read a fairy-tale (B31483). I liked the reading (B31500).

The reading of crime stories was met with positive reactions from children: Will we read the detective story today? (B16491). I wanted this book for Christmas (B17135), maybe I will even get it for my birthday (17702). The session was good, because we have read a detective story (B17639). I also like it the most because of the detective stories (B17640). We learn to think the most during the detective stories (B17649). It is possible to do some thinking during Blanka and Jirka as well, but it is harder. I could not figure it out (B17656), to which another participant said: But even the detective inspectors do not solve all cases (B17668). The reading of the detective story was fantastic (17673). The question, whether they would rather choose the story about Blanka and Jirka, met with a positive reaction to both: Bring Blanka and Jirka (B17721). Detective stories (B17722). The question after detective stories was met also with smiles 
and nodding (B17724). Another time the reaction was: Will we read the detective stories? It was so good the last time (B17818). Will you read us a detective story again (B21523)? A friend of some of the boys participated in one of the sessions, and that is why they asked: Will we read the horror story today (B23495)? I mean, the detective story, so he can hear it as well (B23496). During one of the sessions they were supposed to choose whether to read a detective story or to draw (this activity so far always met with positive reactions) and they have chosen to read a detective story (B35191-B35194).

The participants reacted positively to all books read during the reading group; however, the crime stories got the strongest positive reaction. The selection of texts for the philosophical discussion of Slovak children as well as their opinions on the texts designed for the purpose presents in our opinion a matter suitable for further qualitative as well as quantitative research.

Textbook analysis

The second part of the research was focused on the current Slovak textbooks used during 2015/2016 in compliance with the National educational programme. These include first-year textbooks in line with the innovated education programme and second to fourth-year textbooks in line with the education programme from 2008. Due to the scope of this study we use the method of description and not verbatim transcriptions of textbook materials.

There are textbooks for each year and each subject (some subjects even have more than one textbook approved - the schools can choose which one they prefer). The subjects are divided according to fields of education of the National educational programme.

\section{Selection criteria}

The textbooks used in Slovak schools are approved or recommended by the Ministry of Education. The approved books are also paid for by the Ministry. We have focused on the textbooks that the schools can get for free, thereby setting one of the selection criteria.

Most of the textbooks have an instruction manual for the teacher and workbooks for pupils. We did not take into account any workbooks and focused only on the texts in the textbooks, that was another criterion.

First-year pupils use textbooks where the picture part prevails over the textual part. The only textbook with a longer text is the reading book, and that is why we have eliminated any other first-year textbooks. We examined only the reading book for the first year and the textbooks for the second, third and fourth years.

We have completely omitted textbooks for foreign languages due to the fact that the development of the philosophical thinking is supposed to be based on Slovak or Czech texts and on communication in Slovak.

Due to the scope of this study we have eliminated also textbooks on subjects of ethics and religion. These subjects are part of the field of education Humanity and Values. Both of these subjects focus on the development of critical and independent thinking and the method of discussion is recommended as one of the main methods.
The subject religion includes all Christian denominations present in Slovakia, which also means a lot of textbooks. The results of the examination of the textbooks from these two subjects provide material for a further separate study.

Our aim was to find out, whether the text in the textbooks on natural and social sciences can be at least partially used for the purposes pursued by P4C. At the same time, we wanted to determine, whether the textbooks might contain texts similar to detective stories.

Furthermore, we examined the texts in the textbooks on the subjects in the field of Art and Culture.

Most of our interest was focused on the textbooks in the subject Slovak language and literature, as they contain the greatest variety of non-fiction and fiction texts.

\section{Natural and social sciences}

Since September 2015 the fields of education for primary (ISCED 1) and secondary education (ISCED 2 and 3) have a joint denomination. The education programme for primary education now includes the field Human and Society with the subject local history and the field Human and Nature with the subjects: introduction to science and society and nature studies. For three more years the curriculum will still include the current field of Nature and Society until it will be completely replaced by the two mentioned fields. Starting from the second year up the textbooks correspond to the education programme of 2008

The textbooks contain many topics and texts suitable for the development of critical thinking. They can serve as a starting point for philosophical discussion, though the texts lack the basic attributes of philosophical novels.

\section{Art and culture}

Art and musical education is a part of the field of Art and Culture, the content is specific, focused on the development of psychomotor skills, aesthetical perception and shaping of evaluative thinking.

Textbooks for art education contain a lot of ideas, inspirations for artistic and aesthetical development and creativity. A lot of the tasks or texts can be used for philosophical gymnastic and they can also serve for philosophical discussion.

As with the textbooks for the field Nature and Society the texts in these textbooks do not fulfil the requirements of a story suitable for philosophical discussion.

\section{Slovak language and literature}

The subject Slovak Language and Literature is a part of the field of education "Language and Communication". The first year uses the primer and the reading book. The following years include the textbook for Slovak language and the reading book. The textbooks for Slovak language deal with the topic of linguistic phenomena and communication competencies. Similarly, as in other textbooks, the topics can serve for philosophical discussion or exercise.

Primary-school reading books were of top priority in our research. They are filled with literary texts - in particular non-fiction (prosaic, as well as poetic, mainly epic, but also dramatic). They contain also comics, texts of 
popular science and very rarely non-fiction texts. Tasks for pupils are also a part of reading books. All the tasks are related to the text and aimed at the development of reading comprehension, relationship with literature, communication skills and imagination. The texts develop also cognitive competencies. These are texts from translated, but mainly original Slovak literature for children and youth. In the reading group we have read also Czech texts, but these reading books contain no Czech texts.

The following are the titles of passages and texts, which can be used for the development of philosophical thinking either in form of discussion or exercise (philosophical gymnastics).

One of the reading books (Štefeková et al., 2015, pp. 34-35) for the first year contains the text How Children Fed an Elephant ${ }^{1}$ by Helena Trusková, which is suitable for ethical considerations. The topics include: relationship between mischief, sly and calculating behaviour; disrespecting of bans (e.g. no feeding of animals in the zoo). The same reading book contains a text about the language of animals and things (It is the passage On Various Languages from the book Fairytales for Good Children by Karol Pém, p. 36) with the topic, whether humans can understand animals and things (and vice versa), whether they can communicate with them and why. The text by Viera Janusová What Did Squirrel Long for? (p. 40) is about sadness or rather about the value of freedom and community in contrast to wealth. Excuse Tends to Be Bitter (p. 46) by Elena Čepčeková deals with the consequences of actions, a topic, which we also find in the passage from Krista Bendová Once Upon a Time There Wasn 't... It delves into the question, how it would be, if there were all kinds of things in the world, but no threads (p. 48). The text Flying Grandm by Pavol Štefánik (p. 62) addresses the topic of flying without wings or rather what kind of meaning has the word 'flying'. The passage About Mischievous Grandpa by Martina Bobková (pp. 72-73) deals with the topic of relationships between words or rather collocations, such as: looking for mushrooms collecting mushrooms; fishing - catching fish; picking cherries - combing cherries etc. In Huckleberry (64-65) by Kamila Štefeková the topic follows the questions of the main protagonist: Which blueberry to pick first? Does one need to taste each blueberry first in order to know if it is ripe? When searching for answers to these questions, the children should also explain their reasoning.

Another reading book for the first year (Striežovská et al., 2015) is divided by topics focusing on family, school, seasons, nature, things around us and fairy-tales. The question of names or nicknames appears in the texts Name Wanted (p. 6) by Jana Belašičová or Great FirstGrader's Mystery (pp. 18-19) by Ján Turan. Turan's text also deals with the topic of mystery. The issue of handicaps comes up in the passage Mimi and Liza (Mimi and

\footnotetext{
${ }^{1}$ In the text all titles are written in English, however, in the Bibliography, the titles are written in the languages in which the books were published.
}

Líza are names of two girls; pp. 10-11) by Katarína Kerekesová, Katarína Moláková and Alexandra Salmela (the text contains the visually impaired character of Mimi) and in the text Half of Holidays with Auntie Koliesko (pp. 16-17) by Toňa Revajová (the aunt uses a wheelchair, koliesko means small wheel). The Blackboard by Mária Duríčková can lead to contemplation on the topic of memory, as well as on the topic of being strange, unusual. The topic of honour as well as sadness appears in the text Where Did the Train Go? (pp. 44-45) by Alojz Nociar.

Reader for the second grade of Elementary School by Dienerová et al. (2011) is abundant with prosaic passages from fiction with fanciful characters, but mainly animals. A lot of texts consist of folktales or their adaptations. The development of imagination and an appreciation for art is quite evident in these texts. The topic of fear (its irrationality) and prudence is addressed in the text How We Were Waiting for Christmas by Jana Bodnárová. The text ends with these words: '...Strášik (Strášik is a fairy-tale character of a spook - something scary) disappeared entirely into his secret lair somewhere in Pavlinka's tummy' (p. 45).

In the text Bon Appetite by Hana Zelinová (p. 92) a mother tells her son to go play with something, to which he reacts with the thought, that he does not have something among his toys and therefore he cannot go play with something.

Reader for the third grade of Elementary School by Hirschnerová et al. (2011a) contains more texts than the reading book for the second year and they are longer. These are stories from the life of children. Many of the texts are written in the first person and there is also a text resembling a philosophical novel for children. It is a passage from the already mentioned book by Krista Bendová Once Upon a Time There Wasn't ... (The reading book for the first year by Štefeková et al., 2015, includes another passage from the same book.) The title is Once Upon a Time There Wasn't... But There Was a World Without Teachers (p. 5). The purpose of the text is to prompt a discussion on the role of teachers in the society, whether a teacher is necessary and what it would be like if there were no teachers.

The reading book contains three passages from the works by Jaroslava Blašková - one is from the book Fireworks for Grandpa (pp. 33-35), another from the book Cats in a Poke (pp. 112-113) and there is also the autobiographical text called Green Redcurrant (pp. 103104). The first text is also a part of the reading book for the first year, however in a shorter form. It deals with the issues of whether a person can dissolve or thaw from too much washing and soaping or if it is allowable to recite an occasional poem, if the person who recites it does not agree with the content. Is such a text untrue or possibly even a lie? The second passage is about the relationship between colours and favourite things and food. The characters attribute value to colours according to which thing/food of that colour is their favourite, and therefore they do not accept another colour as valuable. The third 
passage deals with the topic of bans (it is forbidden to eat unripe fruit) and the consequences of their violation (Adam and Eve in the paradise were forbidden from eating the apple, but the bottom line is that they had eaten it).

Little Muk on the Ninth Level by Dana Podracká (pp. 18-19) deals with the topics of reality and imagination or rather the virtual world, as well as the issue of abiding by the rules of games. The question of the real and the imaginary world as well as prejudice comes up in the passage Film about Black Bride by Jana Bodnárová (pp. 118-119) from the book Barbara's Cinema. The passage Telephone from the book The Last Beautiful Stories by Tomáš Čelovský (p. 21-23) deals with the thought of whether it is possible to strangle something that has no throat and also with the issue of lack of time, the hastiness and absentmindedness and their consequences in the life of family members. Adoption is a part of the text by Hana Naglik (women's pseudonym of writer Silvester Lavrík) from the book Ester and Albatros (Ester is name of girl and Albatros - earl Albatros is a mystery creature, pp. 27-28).

The reading book contains also several passages from translated literature. The passage on Pipi Longstocking (p. 48 - 50) by Astrid Lindgren, a part of Matilda by Roald Dahl (pp. 11-13) and Mach a Šebestová (Mach and Šebestová are surnames of little boy and girl) by Miloš Macourek (pp. 6-9) all contain topics such as: an extraordinary person, what is normal - what is not, what is real unreal, etc.

Reader for the fourth grade of Elementary School by Hirschnerová et al. (2011b) contains the text Matthew Book (pp. 8-10) by Jozef Lenhart addressing the topic of valuable and worthless things. This issue is also the topic of the passage Crowy Danka and the Most Precious Things in the World (pp. 64-66) by Jozef Urban. The fairy-tale by Krista Bendová In a Completely Dumb Country (pp. 58-60) deals with several topics suitable for the development of philosophy in children: pointless behaviour, the question of whether something that we do not know about can exist and the challenge to 'Buy, because tomorrow there will be none'. The question of whether another person can hear differently than me is explored by the protagonist in the passage Choir (pp. 8384) by Vincent Šikula; other questions include whether others can see, feel, but also know, think differently/the same as me. The topics of quarrelling, silence (and its connotations) and relations are addressed in the text by Nataša Tanská Mum, Make a Different Silence (pp. 8991). The text How to Paint on the Wall (pp. 93-95) by Ján Milčák explores the topics: painting of the movement of butterfly wings, birdsong, mistakes that lead to sadness, etc. These are topics suitable for the development of creative thinking. The relationship between the mirror which depicts/reflects the reality and paper which reflects the thoughts is a part of the text by Lubomír Feldek From the Life of Mirrors (pp. 112-114).

The use of the textbooks for primary schools is often based on an interactive approach, the pupils are often accompanied by fictional characters who either provide instructions for solving the tasks or take part in solving the task themselves. In most of the textbooks, the approach of constructivism and the respective methodology is employed. The methodology of philosophy according to $\mathrm{P} 4 \mathrm{C}$ is not part of the textbooks, however many texts could contribute to the development of multidimensional thinking as well as cause the discussion. The teachers can use them for philosophical gymnastics.

\section{Conclusion}

Philosophical discussion with pupils can be prompted not only by a text, but also by pictures, movies or other activities. However, a philosophical text is the essential and well-proven means of the development of children's philosophical thinking when applying $\mathrm{P} 4 \mathrm{C}$.

There is also huge potential and lots of possibilities to develop philosophical thinking in its multidimensional aspects through other activities and available literary texts. A practical disadvantage is the fact that the educator has to prepare manuals, which is easier in case of philosophical texts, as the manuals to the stories for philosophical discussions already exist.

Even though the children in our reading group positively reacted to the reading of various texts as well as the related discussions, the reading of criminal stories met with the most positive reactions. This fact could build a basis for further consideration and examination.

When it comes to the analysis of textbooks, apart from one exception we have not discovered any philosophical texts for children in the primary-school textbooks. We have found enough texts to develop philosophical thinking of pupils, for philosophical exercises, as well as for philosophical discussions, especially in the reading books.

Still there is a question, whether the texts are used for philosophical discussion or solely for the purpose specified by the textbook, or whether the philosophical discussion has a place in Slovak schools. These are the questions which should become the subject of further research.

Even though the curriculum requires the development of critical, creative and caring thinking of children, as well as the development of ethical and social behaviour, there is no separate subject dedicated to this development in Slovakia.

Works of non-fiction as well as fiction are of great value and it depends on the reader, whether this value enters his/her life. There is however a difference between the value of the process and the material value. P4C (and the majority of philosophy) commits to values contained in the process. A story written for children for the purpose of philosophical discussion guides the members of the community of inquiry towards equality, nonindoctrination, critical reasoning, unlimited questioning, self-correction, democratic processes. These are the criteria, which determine and govern the philosophical process in the group, the thinking in the dialogue, the children's community of inquiry. Even though in Slovakia there is no literature for the purposes of $\mathrm{P} 4 \mathrm{C}$ and even though it 
seems that there is only a small probability that a new subject could be introduced in the schools, we propose that there are enough opportunities - thanks to other

\section{REFERENCES}

1. Al-Rahman Al-Naqib, A. (1993). Avicenna. In Prospects: the quarterly review of comparative education. Paris: International Bureau of Education. 23(1/2), 53-69.

2. Augustinus Aurelius (1995). O učitel'ovi. Bratislava: Archa

3. Conrad, H. (2006). Kdo je pachatel? Praha: Portál.

4. Creswell, J. W. (2007). Qualitative Inquiry \& Research Design. Choosing among Five Approaches. 3rd edn. London: Sage.

5. Dienerová, E., Nosál'ová, N. \& Hirková, A. (2011). Čitanka pre 2. ročník ZŠ. Bratislava: Aitec.

6. Frenchová, J. (2009). Hitlerova dcéra. Praha: Mladá fronta.

7. Gavora, P. (2007). Sprievodca metodológiou kvalitatívneho výskumu. Bratislava: UK.

8. Ghanizadeh, A. (2017). The interplay between reflective thinking, critical thinking, self-monitoring, and academic achievement in higher education. Higher Education 74(1); 101-114.

9. Hendl, J. (2008). Kvalitativní výzkum. Základni teorie, metody a aplikace. Praha: Portál.

10. Hirschnerová, Z., Filagová, M. \& Ondráš, M. (2011a). Čitanka pre 3. ročník Ž̌. Bratislava: Pol'ana.

11. Hirschnerová, Z., Filagová, M. \& Ondráš, M. (2011b). Čitanka pre 4. ročník ZŠ. Bratislava: Príroda.

12. Laurendeau, P. (2011a). Blanka a Jirka. České Budějovice: TF JU.

13. Laurendeau, P. (2011b). Lukáš a Lenka. České Budějovice: TF JU.

14. Lipman, M. (1974). Harry Stottlemeier's Discovery. Montclair: IAPC.

15. Lipman, M. (1992). On Writing a Philosophical Novel. In A. M. Sharp \& R. F. Reed (Eds.) Studies in Philosophy for Children. Harry Stottlemeier's Discovery (pp. 21-27). Philadelphia: Temple University Press.

16. Lipman, M. (1981). Pixie. Montclair: IAPC.

17. Lipman, M. (1988). Philosophy Goes to School. Philadelphia: Temple University Press.

18. Lipman, M. (2008). A Life Teaching Thinking. Montclair, IAPC.

19. Lipman, M. (2003). Thinking in Education. Cambridge: Cambridge University Press. available texts and other subjects, to apply $\mathrm{P} 4 \mathrm{C}$ elements in the Slovak education.

20. Lipman, M., Sharp, A. M. \& Oscanyan, F. S. (1980). Philosophy in the Classroom. Philadelphia: Temple University Press.

21. Lobel, A. (2008). Kvak a Člup sú kamaráti. Prešov: Slniečkovo.

22. Macků, L. (2010). Filozofický rozměr literárního př́behu. Uplatnění literárního príběhu v programu Filozofie pro děti (diploma thesis - unpublished). České Budějovice: TF JU.

23. Martin, J. R. (1993). Thinking and Literacy. In M. Lipman (Ed.) Thinking Children and Education (pp. 339-412). Dubuque: Kendall/Hunt Publishing Company.

24. Montaigne, de, M. (2007). Eseje. Bratislava: Vydavatel'stvo SSS. SPN.

25. Palouš, R. (1991). K filosofii výchovy. Praha:

26. Pauli, L. (2009). Mutig, Mutig. Zürich: Orell Füssli.

27. Peer, W., Chesnokova, A. \& Springer, M. (2017). Distressful empathy in reading literature: the case for terror management theory? Science and Education, 1, 33-41. Retrieved from: http://scienceandeducation.pdpu.edu.ua/doc/2017/1_2017/ 6.pdf.

28. Sasseville, M. \& Gagnon, M. (2011). Pozorujeme filozofování s dětmi. České Budějovice: TF JU.

29. Silverman, D. (2000). Doing Qualitative Research. A Practical Handbook. London: Sage.

30. Smith, J. A., Flowers, P. \& Larkin, M. (2013). Interpretative Fenomenological Analysis. Theory, Method and Research. London: Sage.

31. Sodtke, M. (2011). Gibt es eigebtlich Brummer, die nach Möhren schmecken? Wien: Lappan.

32. Splitter, L. J. \& Sharp, A. M. (1995). Teaching for Better Thinking: The Classroom Community of Inquiry. Camberwell, Melbourne, Victoria: The Australian Council for Educational Research.

33. Striežovská, J., Pliešovská, V., Belic, M., Bednár, M. \& Belašovičová, J. (2015). Čitanka pre 1. ročník ZŚ - Lipka. Bratislava: Aitec.

34. Štefeková, K., Culková, R. \& Stankovianska, Z. (2015). Čitanka pre 1. ročník ZŠ. Bratislava: Orbis Pictus Istropolitana.

35. Trelease, J. (2013). The Read-Aloud Handbook. 6th edn. New York: Penguin Books. 
Габріела Шарнікова, доктор філософії, доцент, кафедра християнської освіти, теологічний факультет Кирила і Мефодія, Університет Палаџького, вул. Університетська, 22, м. Оломоуи, Чехія

\section{РОЗВИТОК КРИТИЧНОГО МИСЛЕННЯ МОЛОДШИХ \\ ШКОЛЯРІВ ЗА ДОПОМОГОЮ ХУДОЖНІХ ТЕКСТІВ}

Статтю присвячено вивченню особливостей розвитку критичного мислення молодших школярів за допомогою підходу «Філософія для дітей» (Р4С) на основі обговорення художніх текстів. Перше завдання дослідження полягало в аналізі думок дітей щодо текстів та доцільності їх використання для філософських дискусій. Друге завдання полягало в аналізі підручників, що використовуються у початкових школах Словаччини (наявність філософських текстів). Ураховуючи, що в Словаччині Р4С не $є$ популярним, і для дітей майже не передбачено філософських художніх текстів, нас цікавили тексти, які можна було б використати для розвитку когнітивних компетентностей у відповідності до Р4С, такі, що відповідають вимогам освітньої програми у будь-якій звичайній школі. У рамках позакласної діяльності нами проведено 28 дискусій з двома фокусними групами учнів парафіяльної початкової школи. Основна діяльність груп - читання текстів та їх обговорення. Оскільки словацькою мовою не було опубліковано жодного тексту у рамках Р4С, ми вирішили використовувати чеські переклади, оскільки ця мова зрозуміла словацьким дітям, і вони не заперечували проти читання нею. Після прочитання діти ставили запитання, далі йшло їх пояснення, а потім обиралося основне питання, яке учасники хотіли обговорити. У кінці вони повинні були оцінити, наскільки їм сподобався сеанс, обговорити усі позитивні та негативні аспекти. Філософську дискусію з учнями можна проводити не лише за допомогою текстів, але і фотографій, фільмів та інших заходів (особливо з наймолодшими школярами). Проте, філософський текст $\epsilon$ найефективнішим засобом розвитку дитячого філософського мислення при застосуванні Р4С. Діти позитивно реагували на читання різних текстів, а також відповідні дискусії, але кримінальні історії отримали найбільшу кількість позитивних відгуків. Проаналізувавши підручники для початкової школи, ми не виявили в них філософських текстів для дітей, що свідчить про необхідність роботи у цьому руслі.

Ключові слова: навички мислення, філософія для дітей, позакласне заняття, дитяча література, підручник.

Submitted on April, 21, 2017 